\title{
The Level of Knowledge and Opinions of Science Teacher Candidates on Safety Measurements in General Chemistry Laboratory Studies
}

\author{
Nuriye Kocak \\ Correspondence: Nuriye Kocak, Necmettin Erbakan University, Ahmet Kelesoglu Faculty of Education, Section of \\ Mathematics and Science Education, Department of Science Education, Konya, Turkey.
}

$\begin{array}{lcc}\text { Received: July 10,2019 } & \text { Accepted: August 20, } 2019 \quad \text { Online Published: August 22, } 2019 \\ \text { doi:10.11114/jets.v7i11.4378 } & \text { URL: https://doi.org/10.11114/jets.v7i11.4378 }\end{array}$

\begin{abstract}
In general chemistry laboratories of universities, faculty members and students work with chemicals and devices and they are exposed to various risks. For this reason, it is of great importance whether teacher candidates are who are the teachers of future are adequately equipped in terms of laboratory safety or not. This study was conducted on teacher candidates who participated in General Chemistry Laboratory practices in Science Teacher Education program and their opinions and knowledge levels about laboratory safety were investigated. In the study, teacher candidates were informed about the necessary precautions while working in a general chemistry laboratory in 4 courses. Then, in order to increase the awareness and responsibility of the students via the information that taught in courses, the General Chemistry Laboratory Safety questionnaire form given in the appendix was applied. The questionnaire form developed for laboratory safety was applied to 81 teacher candidates. According to the results obtained from the study, it has been found out that teacher candidates mostly find the general chemistry laboratory safety important and understand the importance of information about safety. SPSS 13.0 was used to analyze the consequences of the survey.
\end{abstract}

Keywords: laboratory safety, chemistry, safety, laboratory safety signs

\section{Introduction}

Because of the rapid development of the world with developing modern technology and science, the primary target of the societies should be to produce an information society that produces knowledge and technology, researches and has a scientific thinking structure. The most significant step in the formation of an information society is to educate the new generations in a manner that they can adapt to the changes and developments. And this can only be possible by planning student-centered teaching environments where there is mostly learning by practicing and experiencing. One of the teaching environments in which learning by practicing and experiencing takes place is chemistry labs, laboratory classes are therefore considered to be an important part of the curriculum (Walters et al., 2017). Thanks to these laboratories, students learn the subjects of chemistry more effectively and more meaningfully, create environments in which theoretical knowledge may turn into practice and they learn the significance of systematic, regular and planned work in order to organise new works (Kırbaşlar et al., 2006, Böyük et al., 2010, Can et al., 2015). However, it should be kept in mind that chemistry laboratories are places where accidents may occur at any time and safety rules must be taken into consideration by everyone. The instructions of the responsible instructors, research assistants and technicians must be strictly observed. In addition to learning the basic laboratory safety rules, information is necessary regarding how to work with chemicals safely. It should be kept in mind that many chemicals are flammable, corrosive, toxic, easily oxidizing, harmful, radioactive, irritating or explosive and can easily pass through the skin and may get into the air you breathe (Şeker, 2015, Walters et al., 2017). Paying attention to potential hazards in chemicals in the science laboratory is necessary for teachers (Artdej, 2012). "Laboratory Safety" is defined as a process about approaching the problems with scientific methods, taking measures and identifying the halting points that may occur against the individual himself/herself, equipments and machines while conducting studies and experiments in laboratories (Canel 1995, Aydın et al., 2011, Karabulut, 2016). In all experimental studies, the most important point while working in the laboratory is the "safety". In all studies, safety measures are taken not to limit practical work but to ensure those studies are conducted in a safe manner (Yilmaz \& Morgil, 1999).

In chemistry laboratories, instructors and students work with chemical substances and devices and are exposed to various risks (Kandel et al., 2017). For this reason, there is a requirement for a number of trainings and arrangements in order to minimize the harm by intervening risks that may occur in a conscious way. A Science teacher is competent 
when they knows the dangers and takes precautions in their occupation (Sedghpour et al., 2013). As teacher candidates who are to become science teachers in the future, it is quite important that they are equipped adequately in the education they apply in terms of laboratory safety and that they can apply the information both in their classes and their professional lives. It is about the precision, transmission of knowledge and experiences of instructors when it comes to the fact that the teacher candidates have adequate knowledge and equipment in terms of laboratory safety. It is very important for the students to be aware of the issues related to safety in the laboratory, to behave in a conscious way and to gain a mental habit in this regard. It is also very important for instructors to make the students gain the knowledge and skills related to safety. While fulfilling their responsibilities related to the safety, instructors should apply the safety rules for materials, chemicals and processes, and should have the information and skills necessary to perform the experiments in a safe and an appropriate manner. In order for students to do the activities safely, to gain knowledge, skills and mental habits, and to give importance to safety in their lives, instructors should;

$\checkmark$ use their working area neatly,

$\checkmark$ follow and applying safety instructions,

$\checkmark$ be aware of possible safety problems,

$\checkmark$ watch out the warnings of instructors carefully

$\checkmark$ constantly seek the safety of himself/herself and others should be ensured (Demir, 2016)

According to this aim, this study was carried out to analyze the opinions of science teacher candidates about the laboratory safety and their behaviours regarding obeying the laboratory rules. In order to achieve this goal, it was sought to answer those questions as follows;

$\checkmark \quad$ What are the opinions of teacher candidates about laboratory safety?

$\checkmark \quad$ What are the knowledge levels of teacher candidates about safety of the laboratory and warning and safety signs of the laboratory?

\section{Method}

Survey method was used in this study because it was aimed to reveal the current state of thoughts and knowledge levels of science teacher candidates about the General Chemistry Laboratory Safety because screening models are suitable models for researches aiming to determine the opinions about facts and events, depicts past or present situations as they exist and can be applied on large groups (Kara et al., 2014, Derman \& Çakmak, 2016).

\subsection{Working Group}

The working group of the study consists of 81 first grade students who attend Science Education Department in the Mathematics and Science Education Unit of Education Faculty from a public university in Turkey, and take the General Chemistry Laboratory course.

Subjects of this study were limited to 81 first grade pre-service science teachers. So, the results of this study can not be generalized to all pre-service science teachers. The results of the present study can be generalized to students having the same characteristics in the similar settings.

\subsection{Data Collection}

In the process of the study, an informative presentation about the subtitles of laboratory safety was given by the responsible instructor to the teacher candidates who had taken the course of General Chemistry Laboratory before and it was given in 4 hours of course period.

\footnotetext{
$\checkmark$ Laboratory safety

$\checkmark$ Why is the safety in the laboratory important?

$\checkmark$ General rules to be obeyed while working in laboratory

$\checkmark$ Rules to be obeyed while working with chemicals

$\checkmark$ Material Safety Data Forms and necessary information that it should involve

$\checkmark$ A chemical label example and necessary explanations

$\checkmark$ Giving information about risk(R) and safety(S) phrases in chemical substances

$\checkmark$ Some Warning and Safety Signs

$\checkmark \quad$ Rules to be obeyed while working with glass materials and devices

$\checkmark \quad$ Rules to be obeyed by students in General Chemistry Laboratory
} 
$\checkmark$ Precautions and Safety Measures to Prevent Accidents in General Chemistry Laboratory

$\checkmark$ Rules to be obeyed in accidents that may occur in Chemistry Laboratories

$\checkmark$ First Aid

After the informing presentation, General Chemistry Laboratory Safety Questionnaire Form was applied to the students. In order to identify the opinions knowledge levels of candidates related to the general chemistry laboratory safety, the questionnaire Form developed by Kırbaşlar et al. (2010) was used with some changes and additions. The objective of this study is to investigate the opinions about laboratory safety with 11 items in the first section; to determine the General Chemistry Laboratory Safety Knowledge Level in the second section, and to examine the students' opinions about obeying the laboratory safety rules in the last section. The items related to the questions in the last section are selected from the items that are in General Chemical Laboratory Safety Questionnaire Form stated in the appendix and applied to the students after giving information about safety and that are given pertaining to the laboratory safety rules. The questionnaire form consists of two parts. In the first part of the questionnaire form, 11 questions were prepared to identify teacher candidates' opinions on laboratory safety; in the second part, 16 questions were prepared to determine the knowledge levels of teachers candidates in accordance with the safety information in the information sheet. 7 questions in the $2^{\text {nd }}$ part were prepared as the of form filling blanks questions. The first 7 questions were prepared to evaluate "laboratory safety knowledge", 5-points were given for each correct answer and evaluation was carried out between scores of 0-35 points. Those who scored between 0-17.49 were evaluated as unsuccessful and those who scored between 17.5-35 were evaluated as successful. Other questions were prepared to identify "the information on warning and safety signs". 5-point were given for each correct answer and evaluation was carried out between 0-45 points and those who scored between " $0-22.49$ " were evaluated as unsuccessful and those who scored between "22.5-45" were evaluated as successful.

Within the framework of the study, the questionnaire form used in the study was applied to 81 teacher candidates. $80.2 \%$ $(\mathrm{N}=65)$ of the 81 consist of female teacher candidates while $19.8 \%(\mathrm{~N}=16)$ are male teacher candidates. For the validity of the content, expert opinions were consulted and the questionnaire form questions were formed by taking the feedback into consideration. All results have been evaluated, discussed and suggestions have been presented.

\subsection{Data Analysis}

The data obtained were evaluated according to frequency (f) and percentage (\%) distributions by using the SPSS package program. Descriptive statistics and Pearson's correlation coefficient techniques were used in the analysis of the research results.

\section{Findings}

In this section, the findings obtained from teacher candidates are presented in tables according to the research problems.

Table 1. $(f)$ Frequency and (\%) Percentage Values for the Information Status Variables about General Chemistry Lab Safety

\begin{tabular}{lll}
\hline Information Status about the General Chemistry Lab Safety & f & \% \\
\hline Having no information & 10 & 12.3 \\
\hline Having some information & 46 & 56.8 \\
\hline Having information & 25 & 30.9 \\
\hline Total & 81 & 100.0 \\
\hline
\end{tabular}

In the first part of the questionnaire, first question addressed to teacher candidates was; "Do you find the general chemistry laboratory safety important?" and $96 \%(\mathrm{~N}=78)$ of the teacher candidates expressed that they found the subject of general chemistry laboratory safety important while $4 \%(\mathrm{~N}=3)$ of them stated that they did not find it important. Then second question was addressed to teacher candidates as "What is your knowledge level about general chemistry laboratory safety?" and $12.3 \%(\mathrm{~N}=10)$ of teacher candidates stated that they did not have information, \% $56.8(\mathrm{~N}=46)$ of them stated that they had some information and \%30.9 $(\mathrm{N}=25)$ of them stated that they had information about general chemical laboratory safety (Table 1.). 
Table 2. Opinions about Observing the Safety Rules in Laboratory Practices

\begin{tabular}{|c|c|c|c|c|}
\hline & \multicolumn{2}{|c|}{ Yes } & \multicolumn{2}{|c|}{ No } \\
\hline & $\mathbf{f}$ & $\%$ & $\mathbf{f}$ & $\%$ \\
\hline $\begin{array}{l}\text { 3. Do the chemical substances used in Laboratory of General Chemistry } \\
\text { Practices harm the health of people in some ways? }\end{array}$ & 80 & 98.8 & 1 & 1.2 \\
\hline $\begin{array}{l}\text { 4. Should you be informed about Laboratory Safety before starting } \\
\text { General Chemistry Laboratory practice? }\end{array}$ & 77 & 95 & 4 & 5 \\
\hline $\begin{array}{l}\text { 5. I think everyone who takes the course of General Chemistry and } \\
\text { Laboratory should learn about Laboratory Safety. }\end{array}$ & 80 & 98.8 & 1 & 1.2 \\
\hline
\end{tabular}

The third question addressed to teacher candidates was "Do the chemical substances used in General Chemistry Laboratory practices harm human health in some ways?" and \%98.8 ( $\mathrm{N}=80)$ of the teacher candidates stated that they found it dangerous while $\% 1.2(\mathrm{~N}=1)$ of them stated that they did not find it dangerous. And fourth question addressed to teacher candidates was "Should you be given information about Laboratory Safety before starting General Chemistry Laboratory practice?" and \%95 ( $\mathrm{N}=77)$ of the teacher candidates answered as "yes" while \%5 ( N=4) answered as "no". \%98.8 $(\mathrm{N}=80)$ of the same sample said "yes" for the thought ( $5^{\text {th }}$ question) of "I think everyone who takes the course of General Chemistry and Laboratory should learn about Laboratory Safety" and \%1.2 (N=1) said "no" (Table 2.).

Table 3. Students' Views about Observing the Safety Rules in Laboratory Practices

\begin{tabular}{|c|c|c|c|c|c|c|}
\hline & \multicolumn{2}{|c|}{ I agree } & \multicolumn{2}{|c|}{ I partially agree } & \multicolumn{2}{|c|}{ I do not agree } \\
\hline & $\mathbf{f}$ & $\%$ & $\mathbf{f}$ & $\%$ & $\mathbf{f}$ & $\%$ \\
\hline $\begin{array}{l}\text { 6. The knowledge of a teacher of the course of General } \\
\text { Chemistry and Laboratory is complete as long as s/he is } \\
\text { aware of the risks in her/his job. }\end{array}$ & 34 & 42 & 39 & 48.1 & 8 & 9.9 \\
\hline $\begin{array}{l}\text { 7. First step in providing the safety in the general } \\
\text { chemistry laboratory is the elimination of the conditions } \\
\text { that will degrade health and bring about accidents. So, } \\
\text { the teacher needs to be well-informed. }\end{array}$ & 76 & 93.8 & 5 & 6.2 & - & - \\
\hline $\begin{array}{l}\text { 8. The students should be well-informed about this } \\
\text { subject as well as the teacher. }\end{array}$ & 75 & 92.6 & 5 & 6.2 & 1 & 1.2 \\
\hline
\end{tabular}

As seen in Table 3, sixth view addressed to teacher candidates was "The knowledge of a teacher of the course of General Chemistry and Laboratory is complete as long as s/he is aware of the dangers in her/his job" and \%42 ( $\mathrm{N}=34$ ) of the participants stated that they agreed with this view, \%48 $(\mathrm{N}=39)$ of them stated that they partially agreed with this view and \%9.9 $(\mathrm{N}=8)$ of them stated that they did not agree with this subject. \%93.8 $(\mathrm{N}=76)$ of the students stated that they agreed, \%6.2 ( $=5)$ of the students stated that they partially agreed and none of the students stated that they did not agree with the view of "The first step in providing the safety in the general chemistry laboratory is the elimination of the conditions that will degrade health and cause accidents. For this, the teacher must be well-informed." And \%92.6 $(\mathrm{N}=75)$ of the students stated that they agreed, \%6.2 $(\mathrm{N}=5)$ of them expressed that they partially agreed, \%1.2 $(\mathrm{N}=1)$ stated that $\mathrm{s} /$ he did not agree with the opinion of "The students should be well-informed about this subject as well as the teacher."

Table 4. (f) Frequency and (\%) Percentage Values for the Question about Responsibility of Teachers and Students on Lab Safety

\begin{tabular}{llcc}
\hline 9. In which of the following Laboratory Safety processes, which are under & & $\mathbf{f}$ & $\%$ \\
the responsibility of the teacher, should students take responsibility? & Yes & 60 & 74 \\
\hline Communicating & No & 21 & 26 \\
\hline Planned Action & Yes & 69 & 85.2 \\
& No & 12 & 14.8 \\
\hline Safe Action & Yes & 75 & 92.6 \\
& No & 6 & 7.4 \\
\hline Preparing the Regulation of Laboratory Use & Yes & 16 & 19.8 \\
& No & 65 & 80.2 \\
\hline Making a Checklist & Yes & 15 & 18.5 \\
& No & 66 & 81.5 \\
\hline
\end{tabular}


The question of "In which of the following processes regarding Laboratory Safety of which the teacher is responsible should the students take responsibility?" was approved by $\% 74(\mathrm{~N}=60)$ of the candidates with the phenomenon of communicating, by \%85.2 $(\mathrm{N}=69)$ of the candidates with the phenomenon of planned action, by \%92.6 $(\mathrm{N}=75)$ of the candidates with the phenomenon of safe action but $\% 80.2(\mathrm{~N}=65)$ of the participants stated that they did not agree with the phenomenon of preparing the regulation of laboratory use and \%81.5 $(\mathrm{N}=66)$ of the participants stated that they did not agree with the phenomenon of making a checklist (Table 4.).

A question of "Do you know the warning and safety signs in terms of laboratory safety?" was addressed to teacher candidates and \%19.8 ( $\mathrm{N}=16)$ of them stated that they knew the subject very well, \%79 $(\mathrm{N}=64)$ of them stated that they knew the subject partially and \%1.2 ( $\mathrm{N}=1)$ of them stated that they knew the subject very little.A question of "Do you know the issue of first aid in terms of laboratory safety?" was addressed and \%6.2 $(\mathrm{N}=5)$ of the teacher candidates expressed that they knew the issue very well, \%69.1 ( $\mathrm{N}=56)$ of them stated that they knew the issue partially and $\% 24.7$ $(\mathrm{N}=20)$ of them stated that they knew the subject very little.

Table 5. (f) Frequency and (\%) Percentage Values for General Chemistry Lab Safety Knowledge Level Score

\begin{tabular}{lcc}
\hline Lab safety knowledge level & f & $\%$ \\
\hline Score interval & & \\
\hline $0-17.49$ (Unsuccessful) & 10 & 12.3 \\
\hline $17.5-35$ (Successful) & 71 & 87.7 \\
\hline Total & 81 & 100 \\
\hline Average score & \multicolumn{2}{c}{23.6419} \\
\hline
\end{tabular}

The results of the evaluation of the questions in the information sheet about the knowledge level of teacher candidates in accordance with the safety information in the in the second stage of the questionnaire form is : \%12.3 $(\mathrm{N}=10)$ of the teacher candidates in the sample who scored between 0-17.49 were evaluated as unsuccessful according to their answers to the first seven questions which were formed to determine the General chemistry laboratory safety knowledge level and \%87.7 ( $\mathrm{N}=71)$ of them scored between 17.5-35 and they were evaluated as successful (Table 5.).

Table 6. Frequency (f) and Percentage (\%) Values for Knowledge Level Score of General Chemistry Laboratory Warning and Safety Signs

\begin{tabular}{lcc}
\hline Laboratory safety knowledge level & f & \% \\
\hline Score Interval & & \\
\hline $0-22.49$ (Unsuccessful) & 9 & 11.1 \\
\hline $22.5-45$ (Successful) & 72 & 88.9 \\
\hline Total & 81 & 100 \\
\hline Average Point & \multicolumn{2}{c}{30}
\end{tabular}

$11.1 \%(\mathrm{~N}=9)$ of the teacher candidates who scored 0-22.49 were evaluated as unsuccessful according to their responds to the other nine questions, which were formed to identify the knowledge level of laboratory warning and safety signs, and \%88.9 ( $\mathrm{N}=72)$ of them scored between 22.5-45 and they were evaluated as successful (Table 6.).

Table 7. The Relationship between Laboratory Safety Knowledge Level and Laboratory Warning and Safety Signs Knowledge Level

\begin{tabular}{lccc}
\hline & \multicolumn{3}{c}{ Warning and Safety Signs Knowledge Level } \\
\cline { 2 - 4 } & $\mathrm{n}$ & Pearson's correlation coefficient(r) & $\mathrm{p}$ \\
\cline { 2 - 4 } Laboratory Safety Knowledge Level & 81 & .234 & .036 \\
\hline $\mathrm{p}<, 05$ & &
\end{tabular}

According to Table 7, average score of teacher candidates on "laboratory safety knowledge level" is $23.64(\mathrm{SD}=5.20)$ while their full score is 35 , and average score of teacher candidates on "laboratory warning and safety signs knowledge level" is $30(\mathrm{SD}=6.17)$. When the scores obtained from these two knowledge levels are compared, it is observed that they have achieved a high level of success in both knowledge levels.

As a result of the Pearson's correlation coefficient analysis conducted to determine the relationship between the "laboratory safety knowledge level" and "laboratory warning and safety signs knowledge level", a statistically important positive correlation has been found between the scores at the $\mathrm{p}<.05$ level $(\mathrm{N}=81, \mathrm{r}=0.234, \mathrm{p}<.05)$. 


\section{Discussion and Conclusion}

As a result of the evaluation of the first part of the study which was carried out with $811^{\text {st }}$ grade teacher candidates attending the course of general chemistry laboratory in Science Teaching Department; it is understood that teacher candidates find the issues about general chemistry laboratory safety important but do not have sufficient knowledge about this subject. Similar results were also determined in the studies of Kırbaşlar, Güneş \& Derelioğlu (2010) and Derman \& Çakmak (2016). In these studies, the students also expressed positive opinions about the importance of laboratory safety but they stated that they did not have enough knowledge about laboratory safety. Almost all of the candidates agree that chemical substances, used in General Chemistry Lab Practices, are dangerous for human health in various ways, they should be informed about laboratory safety before starting laboratory practices and everyone should learn the laboratory safety. In other studies related to laboratory safety, it was determined that very few of the accidents occurred in laboratories and workplaces were caused by technical errors and most of them were caused by human errors. It is emphasized that the risks of the laboratory environment and the chemicals used in the laboratory should be determined and in accordance with these risks, the training of the individuals who will use the laboratory should be provided and the necessary safety measures should be taken (Bayrak \& Ağaoğlu, 1999; Yılmaz \& Morgil, 1999; Ateş \& Özarslan, 2014). Teacher candidates come to agreement that the instructors who are in charge of the laboratory should be aware of the dangers of their job, and that the first step of ensuring the safety is that the instructors must have the knowledge and more over the students must also do their parts pertaining to their own safety, but they could not associate this with the adequacy of professional teaching knowledge. Although teacher candidates agree on the idea that both the instructors and the students should be responsible for the issues of communicating, safe action and planned action, they do not think that the control lists and preparing the regulation of laboratory use are within the responsibility of the students (Kırbaşlar, Güneş \& Derelioğlu, 2010 and Derman \& Çakmak, 2016). More than half of the teacher candidates expressed that they partially knew the laboratory safety warning and safety signs and first aid partially and this shows that the instructions given by the instructor about the safety and first aid at the beginning is sufficient, but that repeating those at certain time periods may make them more permanent. It is also stated in the study of Karaca et al. (2006) that it is necessary to remind the safety rules to students frequently in laboratories.

In the first part of the questionnaire most of the students stated that they did not have enough knowledge about laboratory safety but more than $80 \%$ were successful in the second part of the survey according to the score they obtained from both parts of "General Chemistry Laboratory Safety Knowledge Level" and "Laboratory Warning and Safety Signs Knowledge Level". This result shows that the knowledge level of teacher candidates is about $80 \%$, but they do not rely on the information they have and their safety knowledge is at a good level but not enough.

\section{Suggestions}

According to the findings obtained from the research, there are some suggestions below:

$\checkmark$ The high level of knowledge of teacher candidates about laboratory safety has shown that informing candidates about laboratory safety before the lesson is necessary. However, in order to increase this ratio, teacher candidates may be given a more comprehensive, practical and repeated training about laboratory safety by showing some examples of events from daily life (with visuals such as video, slide etc.) before starting the laboratory practices.

$\checkmark$ Explaining the risks that may be encountered in the experiments during their undergraduate education before the experiment may reduce the concerns of teacher candidates and make them more confident and more willing while conducting experiments.

$\checkmark$ There may be warning signs for chemicals and devices used in the laboratory.

$\checkmark$ An education program can be applied to students about what to do after possible laboratory accidents.

\section{References}

Artdej, R. (2012). Investigating undergraduate students' scientific understanding of laboratory safety.Procedia - Social and Behavioral Sciences, 46(2012) 5058-5062. https://doi.org/10.1016/j.sbspro.2012.06.385

Ateş, I., \& Ozarslan, M. (2016). The gifted and talented students science laboratory studies related to safety precautions in views. Journal of Educational Science, 2(3), 42-49.

Aydın, S., Diken, E. H., Yel, M., \& Yilmaz, M. (2011). Determining the knowledge levels of science-technology and biology pre-service teachers about laboratory safety. Gazi University Journal of Gazi Educational Faculty, 31, 583-604.

Bayrak, C., \& Agaoglu, E. (1999). Edt: M. Zor, Laboratory applications and security in science teaching. Anadolu University Open Education Faculty Publications, 595, Eskisehir

Böyük, U., Demir, S., \& Erol, M. (2010). Analyzing the proficiency views of science and technology teachers on 
laboratory studies in terms of different variables. Journal of Tubav Science, 3(4), 342-349.

Can, S., Aksay, E. C. A., \& Orhan, T. Y. (2015). Investigation of pre-service science teachers' attitudes towards laboratory safety. Procedia-Social and Behavioral Sciences, 174, 3131-3136.

https://doi.org/10.1016/j.sbspro.2015.01.1051

Canel, M. (1995). Laboratory safety. Ankara: Ankara University Science FacultyPublications.

Demir, E. (2016). Investigating the physical conditions of the science laboratories and science teachers' level of knowledge about laboratory safety. Master's Thesis, Gazi University, Graduate School of Educational Sciences.

Derman, M., \& Çakmak, M. (2016). Investigation of biology students' perception regarding laboratory safety. Bartin University, Journal of Faculty of Education, 5(1), 178-187. https://doi.org/10.14686/buefad.v5i1.5000161902

Kandel, K. P., Neupane, B. B., \& Giri, B. (2017). Status of chemistry lab safety in Nepal. Plos One, 12(6), 1-10. https://doi.org/10.1371/journal.pone.0179104

Kara, F. N., Aydın, F., Bahar, M., \& Y1lmaz, S. (2014). Pre-service science teachers' views about technology. Abant İzzet Baysal University, Journal of Faculty of Education, 14(1), 118-139. https://doi.org/10.17240/aibuefd.2014.14.1-5000091505

Karabulut, M. (2016). Assessment of chemical exposure and evaluation of risks in chemistry laboratories in universities, ministry of labour and social security. Directorate General of Occupational Health and Safety Thesis for Occupational Health and Safety Expertise, Ankara.

Karaca, A., Ulucinar, S., \& Cansaran, A. (2006). Indication of problems in laboratories in science education. Journal of National Education, 35, 170, 250-259

Kırbaşlar, F. G., Ozsoy, G. Z., \& Derelioglu, Y. (2010). Investigation of pre-service science teachers' opinions and knowledge degrees on laboratory safety, Gazi University Journal of Gazi Educational Faculty, 30, 801-818.

Sedghpour, B. S., Sabbaghan, M., \& Sataei F. M. (2013). A Survey On The Pre Service Chemistry Teachers' Lab Safety Education, Procedia-Social and Behavioral Sciences, 90, 57-62. https://doi.org/10.1016/j.sbspro.2013.07.065

Şeker, E. (2015). An assessment of chemical laboratories at a public university from perspective of occupational safety. Master's Thesis, Okan University, Graduate School of Sciences, İstanbul.

Walters, A. U. C., Lawrence, W., \& Jalsa, N. K. (2017).Chemical laboratory safety awareness, attitudes and practices of tertiary students, Safety Science, 96, 172-182. https://doi.org/10.1016/j.ssci.2017.03.017

Yılmaz, A., \& Morgil, F. I. (1999). Kimya öğretmenligi öğrencilerinin laboratuvar uygulamalarında kullandıkları laboratuvarların şimdiki durumu ve güvenli araştırmaya ilişkin öğrenci görüşleri. Hacettepe Universitesi Egitim Fakultesi Dergisi, 15, 104-109. 


\section{A Questionnaire Form about General Chemistry Laboratory Safety}

1) I find the issue of General Chemistry Laboratory Safety,

$\square$ important $\quad \square$ unimportant

2) What is your knowledge level about General Chemistry Laboratory Safety?

$\square$ I didn't know anything before $\square$ I know a little $\square$ I know

3) Do the chemical substances used in General Chemistry Laboratory practice harm human health in various ways?

$\square$ Yes $\quad \square$ No

4) Should you be informed about Laboratory Safety before starting the General Chemistry Laboratory practice?

$\square$ Yes $\quad$ No

5) I think that everyone who takes the course of General Chemistry and Laboratory should also learn the Laboratory Safety.

$\square$ Yes $\quad \square$ No

6) Do you agree the opinion of "The knowledge of a teacher of the course of General Chemistry and Laboratory is complete as long as $\mathrm{s} / \mathrm{he}$ is aware of the dangers in her/his job"?

$\square$ I agree $\quad \square$ I partially agree $\square$ I do not agree

7) The first step in providing the safety in the general chemistry laboratory is the elimination of the conditions that will degrade health and cause accidents. Therefore, the teacher must be well-informed.

$\square$ I agree $\square$ I partially agree $\square$ I do not agree

8) The students should be well-informed about this subject as well as the teacher.

$\square$ I agree $\quad \square$ I partially agree $\quad \square$ I do not agree

9) In which of the following processes regarding Laboratory Safety of which the teacher is responsible should the students take responsibility? (You can choose more than one option.)

$\square$ Communicating $\quad \square$ Planned Action $\square$ Safe Action

$\square$ Preparing the Regulation of Laboratory Use $\square$ Making a Check List

10) Do you know the warning and safety signs in terms of laboratory safety?

$\square$ I know very well $\square \mathrm{I}$ know partially $\square \mathrm{I}$ know very little

11) Do you know the issue of first aid in terms of laboratory safety?

$\square$ I know very well $\square$ I know partially $\square$ I know very little

\section{A Form of General Chemistry Laboratory Safety Knowledge Level}

\section{General Chemistry Laboratory Safety Knowledge Level}

1) If acid or base is spilled on the skin or eye ..should be washed.

2) ...........can not added into the concentrated acid solution. Because

3) It needs to be very careful while working with acids such as sulfuric acid, nitric acid, hydrochloric acid, hydrofluoric acid and substances containing toxic gases such as bromide, hydrogen sulphide, hydrogen cyanide, chloride and should be studied

4) While heating via the test tube, the cap of the tube should not be working with you and never leave it It may splash to your face.

5) You should absolutely come to the laboratory with. body and the skin . and and if you work with chemicals that can damage the

6) Laboratory accidents are usually caused by should be used.

7) None of the chemical substances in the laboratory and/or or 
1. Laboratory Warning and Safety Signs Knowledge Level: Write down the meanings of the following chemical danger warning signs next to them.

8)

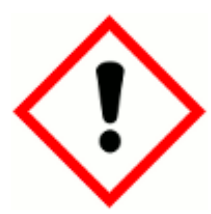

10)

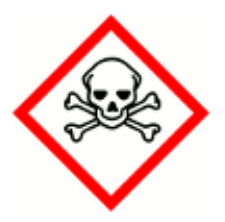

12)

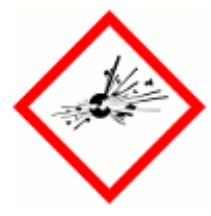

14)

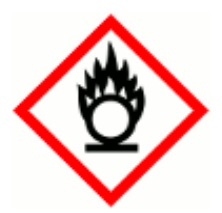

16)

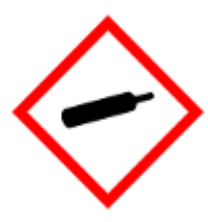

9)

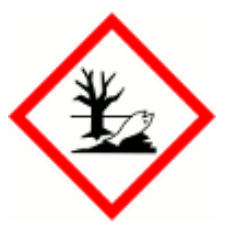

11)

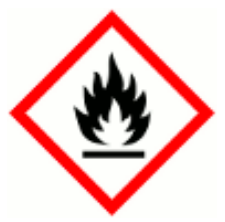

13)

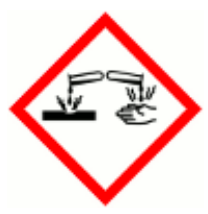

15)

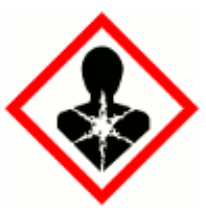

\section{Copyrights}

Copyright for this article is retained by the author(s), with first publication rights granted to the journal.

This is an open-access article distributed under the terms and conditions of the Creative Commons Attribution license which permits unrestricted use, distribution, and reproduction in any medium, provided the original work is properly cited. 